\title{
Economic assesment of neosporosis in beef cattle system performance with different technological levels
}

\section{Avaliação econômica da neosporose no desempenho de sistemas de produção de bovinos de corte com diferentes níveis tecnológicos}

\author{
Jacqueline Cavalcante Barros ${ }^{1}$; Leonardo Francisco Figueiredo Neto ${ }^{2}$; Mayra \\ Batista Bitencourt Fagundes ${ }^{2}$; Renato Andreotti ${ }^{3 *}$
}

\begin{abstract}
The objective of this study was to determine if there is economic losses caused by neoporosis by identifying the number of abortions occurred in beef cattle in the Pantanal region of Mato Grosso do Sul, which are associated with the disease, and then estimate the economic loss to the productive system. 1098 heifers were evaluated from breeding season to the birth of calves in relation to reproductive performance, and the serological diagnosis of neosporosis was performed. To estimate the economic loss it was chosen the projection of exploratory scenarios through simulation using the software Gerenpec/Embrapa. The output rate for heifers seropositive and seronegative to neosporosis was $28.24 \%$ and $50.12 \%$ respectively, showing a $44 \%$ reduction in the output rate of heifers seropositive to Neospora caninum. The evolution of the herd for a period of 10 years showed higher production of animals in the herd free of disease in three technology levels, with values of $7.3 \%, 7.1 \%$ and $8.7 \%$ in stages I, II and III respectively when compared to systems with the disease. By comparing the rate of revenue in the 10 th year of a system free of the disease with an actual observed income over the three levels of technology: the technological level to $14 \%$ revenue I, Level II and $21 \%$ of revenues to the level technological III $34 \%$ higher. Therefore, the study highlights the importance of rural business management geared towards forward-looking vision by identifying trends, behaviors and/or opportunities that will serve as sources for the development of strategic actions, and thus provide increased productivity of rural enterprises eg, methods of neosporosis control using strategies such as the disposal of positive animals.
\end{abstract}

Key words: Heifers, neosporosis, abortion, economic loss

\section{Resumo}

O objetivo deste trabalho foi verificar os prejuízos econômicos associados a neosporose em novilhas de gado de corte, na região do Pantanal Sul-matogrossense. Foram avaliadas 1098 novilhas da estação de reprodução ao nascimento dos bezerros em relação à performance reprodutiva e realizado o diagnóstico sorológico de neosporose. Para estimar a perda econômica foi escolhida a projeção de cenários exploratórios por meio da simulação utilizando o software Gerenpec/Embrapa. A taxa de desfrute para as novilhas soropositivas e soronegativas para neosporose foi de $28,24 \%$ e $50,12 \%$, respectivamente, mostrando uma redução de $44 \%$ na taxa de desfrute de novilhas soropositivas para Neospora caninum. A evolução do rebanho para um período de 10 anos apresentou maior produção de animais para o rebanho livre da doença nos três níveis tecnológicos, com valores de 7,3\%, 7,1\% e 8,7\% nos níveis I, II e III respectivamente quando comparados aos sistemas com a doença. Ao comparar o índice da receita no $10^{\circ}$ ano de um sistema livre da doença com um sistema real observaram-se receitas superiores nos

\footnotetext{
1 Discente da Universidade Federal de Mato Grosso do Sul, UFMS, Campo Grande, MS. E-mail: jacq@cnpgc.embrapa.br

2 Profs. da UFMS, Campo Grande, MS. E-mail: 1ffneto@gmail.com; mayra_bitencourt@yahoo.com.br

3 Pesquisador da Embrapa Gado de Corte, Campo Grande, MS. E-mail: andreott@enpgc.embrapa.br

* Autor para correspondência

Recebido para publicação 19/01/2011 Aprovado em 01/09/2011
} 
três níveis tecnológicos: para o nível tecnológico I receita de $14 \%$, nível II receita de $21 \%$ e para o nível tecnológico III 34\% maior. Portanto, o estudo destaca a importância da gestão do negócio rural voltada para a visão prospectiva, identificando tendências, comportamentos e/ou oportunidades que servirão como fontes para o desenvolvimento de ações estratégicas e, assim, proporcionar aumento da produtividade das empresas rurais, como os métodos de controle da neosporose usando estratégias como o descarte de animais positivos.

Palavras-chave: Novilhas, neosporose, aborto, perda econômica

\section{Introduction}

The production chain of beef in Brazil stands out as a food source of high protein value, and for its capacity to generate jobs and foreign exchange through exports. Since 2003, Brazil leads the world exports of beef, selling 2.1 million tons in 2007, and has the largest commercial herd in the world with 180.3 million head, with 17.3 million heads in Mato Grosso do Sul state (ANUALPEC, 2008).

With the opening of new worldwide markets, standards as quality, lower environmental impact, tracking, competitive price and sanitary requirement, became able to consolidate the international market share. Consequently, economic analysis can indicate the bottlenecks and the farmer can concentrate technological and managerial efforts to achieve its goal of maximizing profits or minimizing costs, providing increased productivity, and thereby ensure the success of his business (LOPES; CARVALHO, 2002).

Acurrent example of sanitary barriers is the FMD control policy, which receives a distinct treatment, but with the growing demand of international markets other diseases can potentially be included in the health agenda. The study of the economic impact of a disease can identify how it affects the profitability of cattle production system and serve as a parameter to justify public policies to control the industry.

The Neosporosis, a disease caused by protozoan Neospora caninum has emerged as an important disease in cattle with worldwide distribution and is related to reproductive failure, and the dog being the definitive host. Once installed, the disease is transmitted from mother to child possibly for several generations (DUBEY; SCHARES; ORTEGAMORA, 2007). In Mato Grosso do Sul, serological tests showed the presence of Neosporosis in 30\% of heifers (ANDREOTTI et al., 2004), 29.5\% of embryos recipient heifers of beef cattle raised in extensive regime (PAZ; LEITE; ROCHA, 2007) and Oshiro et al. (2007) identified the presence of $N$. caninum in $14.9 \%$ of cows in the beef cattle herd of the state, where $69.8 \%$ of the herds studied showed the presence of Neosporosis, linking abortion as a risk factor associated with the disease.

In the beef industry cow-calf system (cows, heifers and bulls) represents about $56 \%$ of the workforce of the Brazilian herd (ANUALPEC, 2008), heifers in the breeding season represent a bottleneck in the reproductive system, even under favorable conditions (VIEIRA et al., 2005).

In Brazil, factors that measure the efficiency of cow-calf system, such as pregnancy rates, birth rate, weaning rate, weaning weight, productivity of weaned calves, age at first calving, are still poorly understood (JORGE JUNIOR; CARDOSO; ALBUQUERQUE, 2006). There are few studies that estimate cost and economic loss related to disease in animals (ALMEIDA et al., 2006; HOLANDA JUNIOR et al., 2005), in relation to Neosporosis, there are not reports about in the country (ANDREOTTI et al., 2010).

The aim of this study was to determine whether there is economic loss caused by Neosporosis using the number of abortions occurred in heifers of beef cattle as an indicator, and estimate the economic loss considering the production system in different technological levels. 


\section{Material and Methods}

The present study was conducted on a farm, located in the municipality of Miranda - MS $\left(20^{\circ}\right.$ 06 '05 'S $56^{\circ} 47^{\prime} 43^{\prime}$ ” W), whose production system is composed of three phases; cow-calf system, rearing and fattening. The field system is characterized by low stocking pasture with defined breeding season and examination of bulls with separate management of heifers in relation to breeding cows.

For the sample size it was used the population proportion estimate $\left(\mathrm{n}=(\mathrm{Z} \alpha / 2)^{2} \cdot 0,25 / \mathrm{E}\right)$ according to Levine, Berenson e Stephan (2000) with 95\% confidence interval and error of $3 \%$. It was analyzed a total of 1098 Nellore heifers with an average age of 24 months and mean weight of $259.14 \mathrm{~kg}$. The animals were placed in the mating system based on artificial insemination with clean up bulls (1:35) from November 2007 to March 2008 and followed up throughout the reproductive system until the first months of life of the calves.

Primary data regarding the diagnosis of heifers pregnancy, weight of the female at the beginning of the breeding season, and the births of the calves was raised on the property, and data regarding the diagnosis of neosporosis in heifers were developed in the laboratories of Embrapa Beef Cattle.

Information on the herd were based on routine farm management. There were two blood samples in cows, one in the diagnosis of pregnancy, around 60 days of breeding, and another one month after delivery, and a collection of blood of calves around a month old. The sera, after identification, were stored at $-20^{\circ} \mathrm{C}$ until serological testing.

The samples were examined by IFA to detect antibodies against $N$. caninum. The antigen was produced in a tachyzoites culture of $N$. caninum strain NC-1 (DUBEY et al., 1988) in Vero cells (OLIVEIRA et al., 2004). Commercial conjugated anti-bovine IgG (Sigma) was used at a dilution of $1: 10,000$ and the samples were tested at dilution of 1:50 (PARÉ; THURMOND; HIETALA, 1996). In each slide included a negative control serum and a positive.

For the statistical analysis of prevalence obtained by relating the diagnosis of neosporosis in heifers and abortion or conception (birth), it was used $2 \times 2$ contingency tables and significance determined by Chi-square test $(\chi 2)$, using the statistical software.

To estimate the economic loss it was chosen the projection of exploratory scenarios through simulation of a possible future using the software Gerenpec Embrapa Beef Cattle, with the establishment of certain conditions of a production system based on the parameters of the real system under study. According to Schwartz (2000) the elaboration of scenarios is a creative projection of likely behaviors to situations in the future that means embracing a vision of long-term future in an uncertain world.

In drawing up the scenarios we used the software Gerenpec ${ }^{\circledR}$, developed by Embrapa Beef Cattle, which is an application that simulates the development of a beef cattle farm for ten years, allowing you to define, predict and consolidating figures for cattle, and the production system (COSTA; CORRÊA; FEIJÓ, 2004).

In this study, the characterization of production systems of cattle took into account the technological level of production practiced by farmers on their properties, thus the production systems were classified as technological level I (level I), technological level II (level II) and technological level III (level III). This classification as a basis for analysis is justified because the presence or absence of disease in the herd can express different economic effects according to different technological practices adopted by the system of production.

The technological level I reflected the conditions described by Costa et al. (2005), characterized by low-tech production systems. According to Corrêa et al. (2006) was defined improved production systems with the use of an average technology and adoption of good practices of beef cattle management, which characterized the technological level II. 
The production system with technological level feeding in the pasture for finishing animals. The III is described with the use of high technology, using the estimates observed in experiments conducted by Zimmer e Euclides Filho (1997), which beyond the application of good practices in beef cattle management also makes supplementary

general characteristics of technological practices adopted in production systems as defined in this study were based on good agricultural practices (VALLE, 2010) (Table 1).

Table 1. Practices adopted in the production system for beef cattle according to the technological level.

\begin{tabular}{|c|c|c|c|}
\hline Adopted practices & Level I & Level II & Level III \\
\hline \multirow{8}{*}{ Property Managenment } & No formal planning & Has development project & Has development project \\
\hline & Decisions are made & Decisions are & Decisions are \\
\hline & empirically & studied & studied \\
\hline & it No control of income & Control of income & Control of income \\
\hline & and expenditure & and expenditure & and expenditure \\
\hline & $\begin{array}{l}\text { No zoothecnical } \\
\text { indexes' records }\end{array}$ & $\begin{array}{c}\text { Control of zoothecnical } \\
\text { indexes }\end{array}$ & $\begin{array}{c}\text { Control of zoothecnical } \\
\text { indexes }\end{array}$ \\
\hline & No animal control & Individual control & Individual control \\
\hline & & of animals & of animals \\
\hline \multirow{3}{*}{ Pasture management } & Overgrazed practice & Correct management & Correct management \\
\hline & Makes periodic mowing & & \\
\hline & No nutrient restoration & $\begin{array}{l}\text { Periodically restore } \\
\text { the nutrients }\end{array}$ & $\begin{array}{l}\text { Periodically restore } \\
\text { the nutrients }\end{array}$ \\
\hline Supplementary feeding & $\begin{array}{l}\text { Innapropriate mineral } \\
\text { supply }\end{array}$ & $\begin{array}{l}\text { Mineral supply } \\
\text { of high quality }\end{array}$ & $\begin{array}{c}\text { Mineral supply } \\
\text { of high quality } \\
\text { Makes supplementary } \\
\text { feeding on pasture or feedlot }\end{array}$ \\
\hline \multirow[t]{2}{*}{ Health management } & Misuse of antiparasitic & $\begin{array}{c}\text { Makes strategic } \\
\text { control of parasites }\end{array}$ & $\begin{array}{c}\text { Makes strategic } \\
\text { control of parasites }\end{array}$ \\
\hline & $\begin{array}{l}\text { Uses only mandatory } \\
\text { vaccinations }\end{array}$ & $\begin{array}{l}\text { Obey vaccination } \\
\text { calendar }\end{array}$ & $\begin{array}{l}\text { Obey vaccination } \\
\text { calendar }\end{array}$ \\
\hline \multirow{6}{*}{ Breeding management } & $\begin{array}{l}\text { Breeding during } \\
\text { the year }\end{array}$ & $\begin{array}{l}\text { Breeding during } \\
\text { three months }\end{array}$ & $\begin{array}{l}\text { Breeding during } \\
\text { three months }\end{array}$ \\
\hline & $\begin{array}{l}\text { No bull andrologic } \\
\text { evaluation }\end{array}$ & $\begin{array}{l}\text { Bull andrologic } \\
\text { evaluation }\end{array}$ & $\begin{array}{l}\text { Bull andrologic } \\
\text { evaluation }\end{array}$ \\
\hline & No pregnancy diagnosis & Pregnancy diagnosis & Pregnancy diagnosis \\
\hline & $\begin{array}{l}\text { Discards cows } \\
\text { by age }\end{array}$ & $\begin{array}{l}\text { Discards cows for } \\
\text { productivity }\end{array}$ & $\begin{array}{l}\text { Discards cows for } \\
\text { productivity }\end{array}$ \\
\hline & $\begin{array}{c}\text { Unsatisfactory } \\
\text { care of newborns }\end{array}$ & Special care for newborns & Special care for newborns \\
\hline & $\begin{array}{l}\text { Does not separate } \\
\text { animals by categories }\end{array}$ & $\begin{array}{l}\text { Separates animals } \\
\text { by categories }\end{array}$ & $\begin{array}{l}\text { Separates animals } \\
\text { by categories }\end{array}$ \\
\hline
\end{tabular}

Source: from Valle (2010). 
The technical coefficients also reflect the technological standard adopted on farms, because they demonstrate the performance of the flock, so these livestock indicators served as a reference in the construction of a modal system according to each level of technology (Table 2).

Table 2. Key zootechnical indicators according to technological standard.

\begin{tabular}{lcccc}
\hline Zootechnical parameter & Unit & \multicolumn{3}{c}{ Production system } \\
\cline { 3 - 5 } & & Level I & Level II & Level III \\
\hline Birth & $\%$ & 60 & 80 & 80 \\
Mortality 0-1 & $\%$ & 6 & 3 & 3 \\
Mortality 1-2 & $\%$ & 2 & 1 & 1 \\
Cow Mortality & $\%$ & 2 & 1 & 1 \\
Cow disposal & $\%$ & 15 & 20 & 20 \\
Bull disposal & $\%$ & 15 & 20 & 20 \\
Age of first calving & Anos & 4 & 3 & 2 \\
Supportability & UA/ha & 0,6 & 1,15 & 1,6 \\
Bull/Cow & - & $1 / 25$ & $1 / 35$ & $1 / 35$ \\
\hline
\end{tabular}

Source: Costa et al. (2005), Corrêa et al. (2006), Zimmer and Euclides Filho (1997).

\section{Results}

Analysis of blood samples in the first and second collection of cattle showed the same results by IFA, only three sera turned positive for the second collection in this way, we considered the information of those who had two positive tests, to analyze the results of serological and its association with the birth.

To verify if the frequency of abortions occurred in the sample were associated with the presence of neosporosis in a herd there was a pregnancy diagnosis by palpation, in which it was met a total of 546 pregnant heifers which corresponds to $49.73 \%$. The heifers that were negative for the disease in pregnancy had a loss of $40.88 \%$ and the positive the value of $55.89 \%$.

To verify that the frequency of abortions occurring in the sample were associated with the presence of neosporosis was observed in the herd pregnancy diagnosis by palpation, in which was observed a total of 546 pregnant heifers which corresponds to $49.73 \%$. The negative heifers for disease was observed pregnancy loss in a $40.88 \%$ and the positive heifers with value of $55.89 \%$ (Table 3).

Table 3. Evaluation of heifers in relation to neosporosis diagnosis,pregnancy birth.

\begin{tabular}{lcclccc}
\hline \multirow{2}{*}{ Neosporosis in heifers } & \multicolumn{2}{c}{ Pregnancy diagnosis } & & \multicolumn{2}{c}{ Birth } & Birth rate \\
\cline { 2 - 3 } & Pregnancy(\%) & empty (\%) & & Conception & No conception & \\
\hline Positive & $303(44,11)$ & $384(55,89)$ & & 194 & 493 & $28,24 \%$ \\
Negative & $243(59,12)$ & $168(40,88)$ & & 206 & 205 & $50,12 \%$ \\
Total & $546(49,73)$ & $552(50,27)$ & & 400 & 698 & $36,43 \%$ \\
\hline
\end{tabular}

Source: Research data held. 
In this work, to demonstrate the impact of disease on reproductive performance of heifers were tested the significance of association between two qualitative variables: the cases of abortion and seropositivity for neosporosis (Table 4).

It was found the value of $\chi^{2}=28.58$ with a significance level of $0.01 \%(\alpha=0.0001)$ and degree of freedom $(\mathrm{df}=1)$, and it was concluded that there is significant difference between the proportion of births of positive calf heifers and the proportion of abortions in heifers positive for neosporosis.

Table 4. Relationship between heifers positive for neosporosis and abortion.

\begin{tabular}{lccc}
\hline Heifers & Pregnancy diagnosis & \multicolumn{2}{c}{ Conception } \\
\cline { 3 - 4 } & & Birth & Abortion \\
\hline Positive & 303 & 194 & 109 \\
Negative & 243 & 206 & 37 \\
Total & 546 & 400 & 146 \\
\hline
\end{tabular}

Source: Research data held $(\mathrm{P}<0,0001)$.

In this herd, the off take rate averaged $36.43 \%$ comparing this rate (heifers in a real herd) with a production rate of negative heifers of $50.12 \%$ (herd without the disease) (Table 4) showing a difference in the amount of $13.69 \%$, which means a herd of heifers had a real loss in its birth rate in relation to a herd of heifers without the presence of neosporosis.

In field conditions, the general herd of a production system for beef cattle is composed of various categories of animals (cows, heifers, calves, males, bulls and cow herders). Within the phase of cow-calf the reproductive system is composed of $80 \%$ of cows and $20 \%$ of heifers, making the participation of the heifers loss of $13.69 \%$ represent only a proportional reproductive impact of $2.73 \%$ of animal losses in the general herd.

To analyze the economic impact of neosporosis on the productive system of the State of Mato Grosso do Sul two systems of production for each technology level with a time horizon of ten years were simulated, one representing livestock indicators in real conditions found in the literature, ie a herd with the presence of disease, and one without disease and with only an increase in birth rate of $6.01 \%$ compared to initial husbandry values.

In the simulation, using the software Gerenpec (EMBRAPA GADO DE CORTE, 2010) it was held constant for all levels of technology the initial herd variables, weight and price of lean cattle, weight and price of fed cattle and livestock sales planning by category: the annual components of total revenues were calves (as), fat calf, calf early, male fat and cow (cows over 60 months destined for disposal).

Graphs 1 to 3 show the profile of the three levels of technology in relation to the herd and their production, comparing the two production systems in a time span of ten years. The two production systems of technological level I, both the real and free of disease, showed, on average, a negative trend in the herd growth rate of $-2.35 \%$ and $-1.19 \%$ per annum respectively, which resulted in a reduction in inventory of cattle at the end of the simulated period (Graphic 1).

A similar situation occurred with the annual production growth rate of livestock, this production being the number of heads sold annually in the different categories that make up the recipe, this rate from the fifth year was also negative for both the real scenario $(-3.55 \%$ on average) and for the disease-free scenario $(-1.93 \%$ on average), reflecting the downward trend in the evolution of the herd (Graphic 1). 
Graphic 1. Trend of the evolution of their livestock and animal production in systems with technological level I.

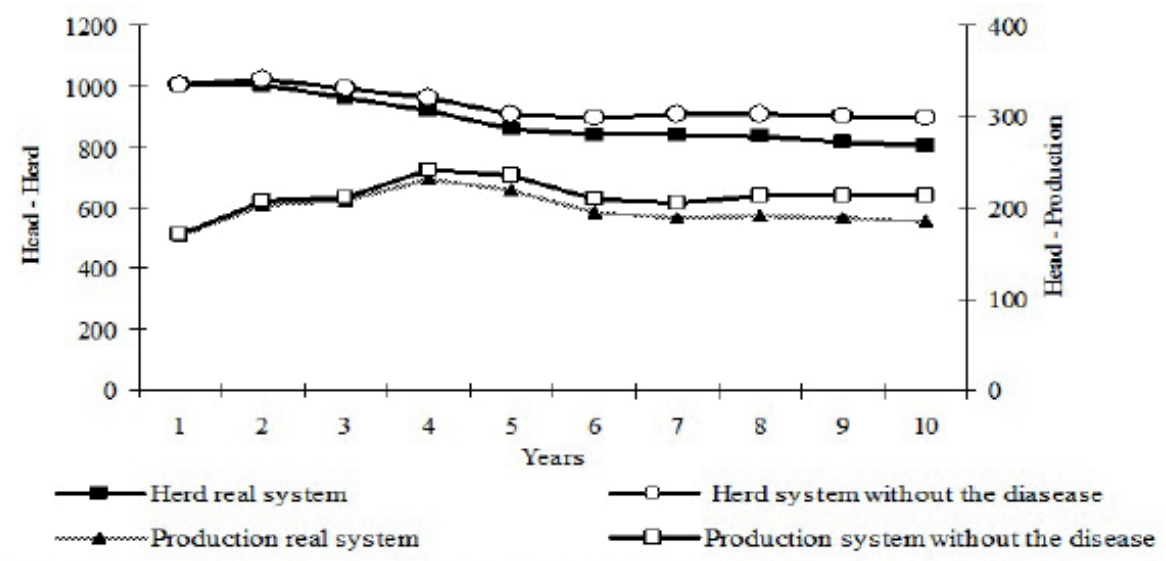

Note: In the left of the graph shows the scale of the number of cattle heads in total, and in the right to scale the number of head sold

At the technological level II, the real production system showed a trend in the herd growth rate averaged at $2.7 \%$ per annum, and the system free of disease an average rate of $3.99 \%$ per year, which allowed an increase in stocks of these herds at the end of the period, and boosted the production of animals annually. The average production growth rate of livestock was $8.89 \%$ per annum for the real system, and $10.16 \%$ per annum for the system without the disease, which means that this system produced last year, on average, $14.33 \%$ animals more than the first (Graphic 2).

Graphic 2. Trend of the evolution of their livestock and animal production in systems with technological level II.

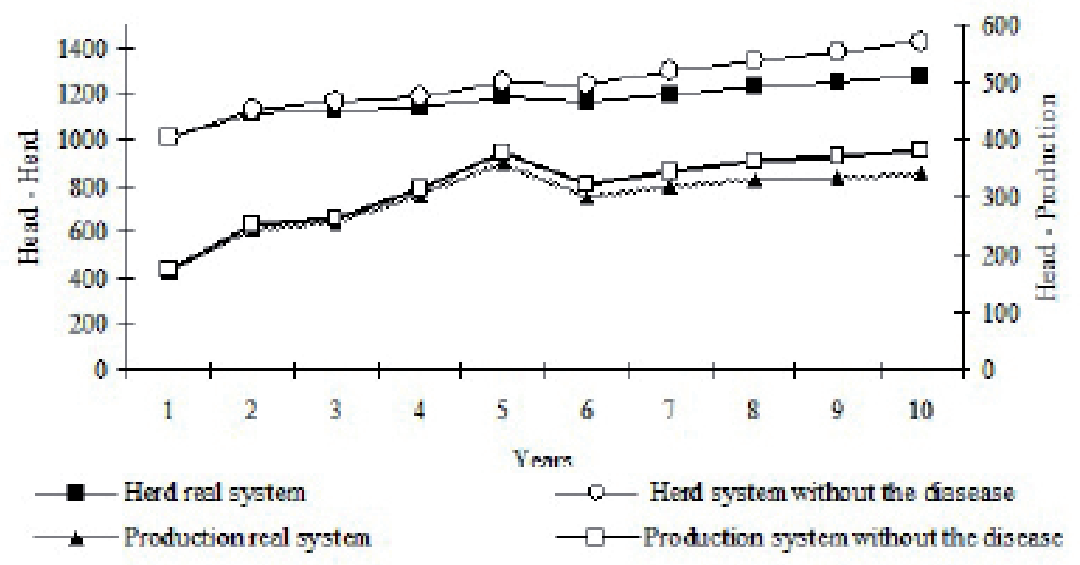

Note: In the left of the gragh shows the s cale of the mamiber of cottle be ads in totel, and in the tight to ac als the mumber of head oold

For the level III technological standard, the real production system and the system without the disease had herd growth rates averaged at $4 \%$ and $5.6 \%$ per annum respectively, which resulted in a behavior of livestock inventory and animal production similar to the technology level II (Graphic 3). 
Graphic 3. Evolution of herd and livestock production in the system with technology level III.

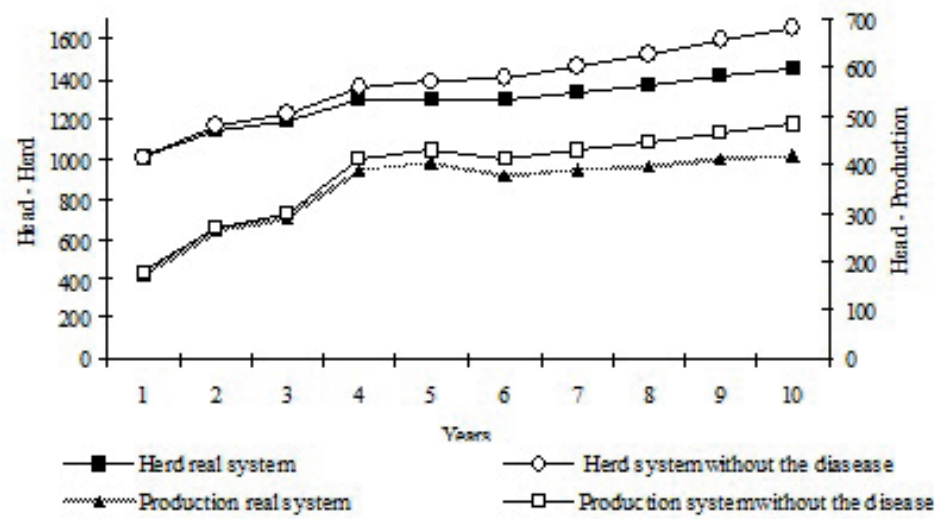

Note: In the left of the graph shars the scale of the number of cattle heads in total, and in the right to scale the number of head sold.

Regarding the average animal production growth rate, for the real system it was $11.4 \%$ per annum, and for the system without the disease it was $13 \%$ per year, which also produced every year, on average, $14.37 \%$ animals more than the first (Graphic 3). At the end of the period of 10 years, at the technological level I, the disease-free production system presented an animal production $7.3 \%$ higher in comparison to the system under real conditions. For the level II production system the difference was $7.1 \%$ higher and for the level III production system the difference was $8.7 \%$ higher.

The three production systems without the disease had growth rates in relation to total production of animals, which reinforces the claim that Neosporosis, when endemic, acts in a discreet manner, being quiet and regular, causing low impact over a period, what may hinder the effort of the producer to increase the productivity of his herd. For the systems using higher technology, such as technological levels II and III, the disease control showed a more efficient animal production outcome, because this production still increases throughout the period of 10 years, which suggests a greater impact on revenue.

Since the annual revenue was the product of the yearly animal production by its price, according to the animal type, to check the revenue variation occurred each year (over 10 years) and compare the real production systems and disease-free, according to the technological level, it was constructed the index of the annual income having as a base period the year one.

At the technological level I after the 5th year for both the real system and the system without the presence of Neosporosis, revenues presented an unstable evolution due to the downward trend in the annual animal production. In the 10th year the real system obtained a $19 \%$ annual revenue exceeding the revenue of the first year, while the system free of the disease had a revenue $33 \%$ higher (Table 5).

Table 5. Index of annual revenue in the real productive system and the free of neosporosis productive system according to the technology standard (Base: year 1).

\begin{tabular}{lcccccc}
\hline Year & \multicolumn{2}{c}{ Level I } & \multicolumn{2}{c}{ Level II } & \multicolumn{2}{c}{ Level III } \\
& Real & Free & Real & Free & Real & Free \\
\hline 1 & 100 & 100 & 100 & 100 & 100 & 100 \\
2 & 139 & 139 & 157 & 158 & 165 & 165 \\
3 & 146 & 146 & 164 & 164 & 175 & 176 \\
4 & 162 & 165 & 210 & 215 & 247 & 255 \\
5 & 159 & 168 & 241 & 249 & 266 & 277 \\
6 & 118 & 125 & 180 & 190 & 231 & 247 \\
7 & 115 & 123 & 201 & 214 & 240 & 260 \\
8 & 122 & 134 & 208 & 226 & 245 & 270 \\
9 & 123 & 135 & 208 & 226 & 253 & 280 \\
10 & 119 & 133 & 213 & 234 & 259 & 293 \\
\hline
\end{tabular}


For the technological level II, the annual revenue for both systems had a rising trend: at the end of the 10 year period the annual revenue was more than $113 \%$ higher than the first year revenue for the real system, and $134 \%$ higher for the system free of disease. At the technological level III, the annual revenue of the final year of study was $159 \%$ higher than in the first year, and the annual revenue of the system free of the disease was $193 \%$ higher for the same date basis.

Comparing the percentage variation rates of income index between the two production systems (disease-free and real) of every technological level, the difference was the economic loss to the real production system in accordance with each technological standard along the period of 10 years.

By comparing the rates of income between the two systems, disease-free and real system, within each level of technology, and considering the evolution period of the herd, the difference between them showed that there is a real revenue gain that is higher for the system free of disease in all three technology levels, and this difference is greater the higher the technological level is (Graphic 4).

In the 10th year for Level I, the production system free of the disease reported a revenue $14 \%$ superior to the revenue of the date basis in relation to the real system. Level II had revenues $21 \%$ superior and the level III showed 34\% higher revenue than the real system.

Graphic 4. Evolution of growth rates of revenues index from production systems free of neosporosis compared with real systems according to the technological standard.

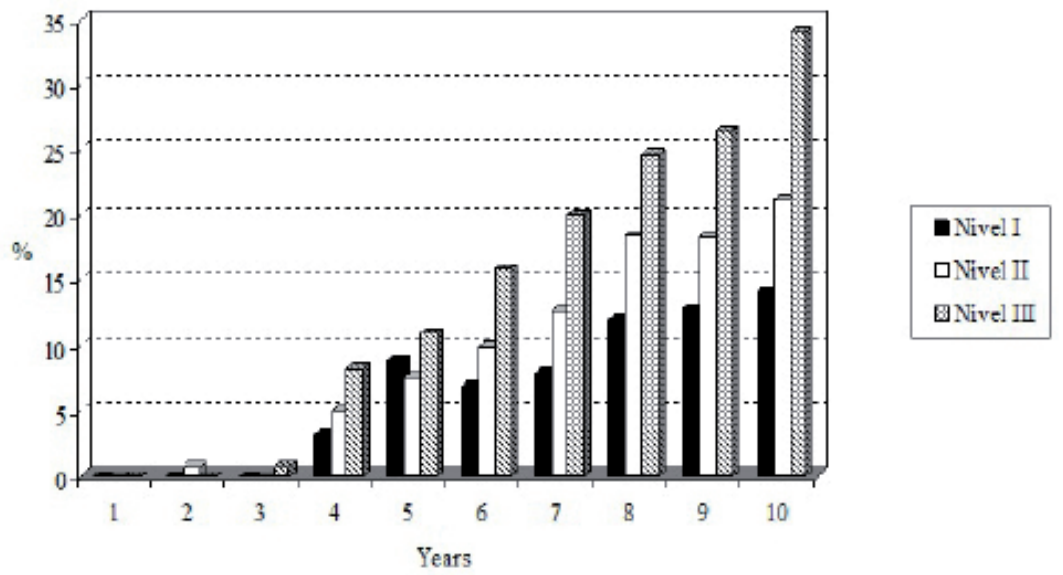

\section{Discussion}

Not yet a consensus regarding a cutt-off value that should be the reference for the diagnosis of neosporosis and it can be influenced by age or stage of disease in animals, strategy of diagnostic evaluation and laboratory conditions (ALVAREZGARCIA et al., 2003, VON BLUNRÖDER et al, 2004; DUBEY, SCHARER, 2006). Serological tests to identify infected animals, may require a higher sensitivity, lower cut-off than should be suggested for the diagnosis of bovine abortion. In the state of
Mato Grosso do Sul the epidemiological survey was carried out with the cutoff of 1:50 (OSHIRO et al., 2007; ANDREOTTI et al., 2010). For these reasons we defined a cut-off with a tendency to give greater sensitivity to the test (1:50).

In assessing the presence of disease in the herd studied the value of $36.43 \%$ was similar to that found by Andreotti et al. (2004) value of 30\% in heifers of beef cattle, and by Paz, Leite e Rocha (2007) where $29.5 \%$ were found positive animals using embryo recipient heifers for beef cattle. 
The birthrate, or benefit, for heifers seronegative and seropositive for neosporosis was $50.12 \%$ and $28.24 \%$ respectively, indicating that the production rate of heifers with Neosporosis was $44 \%$ lower than the negative. When comparing the benefit index value of Neosporosis negative heifers (50.12\%) with birth rates and weaning in beef cattle herd, raised in native pastures of the Pantanal (CADAVID GARCIA, 1981; 1986) that are between 50 and $58 \%$, it is possible to observe that they are close. However, these values are low compared to the cerrado region.

The results of this study reinforce the information collected by Oshiro et al. (2007) that showed a prevalence of $14.8 \%$ to neosporosis in cows and in cattle in Mato Grosso do Sul and identified abortion as a risk factor associated to neosporosis. To demonstrate the impact of disease on reproductive performance of heifers the significance of association between two qualitative variables was tested: the cases of abortion and seropositivity for neosporosis.

According to Oshiro et al. (2007) there is an epidemiological assessment of the percentage of contamination with Neosporosis in cattle herd of $14.9 \%$ in the state of Mato Grosso do Sul. Since cows represent $80 \%$ of the reproductive management herd, proportionally the loss impact is of $3,28 \%$. The sum of the impact of both categories leads to a total loss of $6,01 \%$ on the reproductive performance.

Under normal conditions and maintaining the variables constant, the two level I production systems suggest a level of producer decapitalization in a long term period, because even with an increase in one of the indicators of the livestock production system without the disease, both fail to maintain the herd stock, a fact that may influence animal production and compromise the stability of the rural business in virtue of its revenue. This observation is supported by work as Cezar et al. (2005) where the authors, after identifying the decapitalization of the producers of beef cattle farms in traditional medium sized companies in Brazil.

Constraining the producer's capital conditions, technological changes implemented have improved the performance parameters, but these were still low so that the system could achieve efficiency, meaning that the production system was not able to pay in full the factors of production used, leading to the process of disinvestment of the producer (CEZAR et al., 2005). A similar conclusion was presented by Costa et al. (2008), which estimated the cost of production at sign of the ox for the State of Mato Grosso do Sul using as basis the production system most frequently adopted, which is characterized by the use of low technology. It was found that the revenue was not enough to cover the total cost, profit was negative, and the costs to produce a bushel of live cattle were higher than the market price, not rewarding the factors of production used and promoting the decapitalization of the producer by the non-payment of interest on the employed capital.

In this study the revenues were also analyzed by the software Gerenpec, where there was the inclusion of data on prices and planning of livestock sales by category and the program generated total revenues based on the simulation of livestock production in each production system. The prices of animals that were fed into the software Gerenpec were based on the price offered by specialized web page Boi \& Companhia (2005) at the time of analysis.

In general, the disease control has brought a greater impact on the evolution of annual revenue for the technological level III, so properties that make use of high technology as a supplement to pasture, confinement may have an economic loss of at least $34 \%$ over a period of 10 years. Thus, the economic losses to the technological levels I and II may be $14 \%$ and $21 \%$ respectively, while the first refers to the property with the use of low technology, and the second represents properties that make use of technology, but have not invested 
in feedlot or animal supplementation. The higher the technological system the greater is the loss of revenue without the control of the disease.

In this study it was possible to conclude that there was a negative impact on the herd benefit rate with the presence of cows seropositive for neosporosis. The evolution of the herd, for a period of 10 years, presented a higher animal production for the disease-free herd in the three technological levels when compared to the systems with the disease. By comparing the rate of revenue within the 10 year period of a system free of disease with a real system, there were higher revenues in the three levels of technology, and the higher the technological level the higher the revenue level.

\section{Acknowledgements}

The authors acknowledge project funding by $\mathrm{CNPq}$ and Embrapa.

\section{References}

ALMEIDA, M. B.; TORTELLI, F. P.; CORRÊA, B. R.; FERREIRA, J. L. M.; SOARES, M. P.; FARIAS, N. A.; CORRÊA, F. R.; SCHILD, A. L. Tristeza parasitária bovina na região sul do Rio Grande do sul: estudo retrospectivo de 1978 - 2005. Revista Pesquisa Veterinária Brasileira, Seropédica, v. 4, n. 26, p. 237242, 2006.

ALVAREZ-GARCIA, G.; COLLANTES-FERNANDEZ, E.; COSTAS, E.; REBORDOSA, X.; ORTEGA-MORA, L. M. Influence of age and purpose for testing on the cut-off selection of serological methods in bovine neosporosis. Veterinary Research, Paris, v. 34, n. 3, p. 341-352. 2003.

ANDREOTTI, R.; PINCKNEY, R. D.; PIRES, P. P.; SILVA, E. Evidence of Neospora caninum in beef cattle and dogs in the state of Mato Grosso do Sul, Center-Western Region, Brazil. Revista Brasileira de Parasitologia Veterinária, São Carlos, v. 13, n. 3, p. 129131, 2004.

ANDREOTTI, R.; BARROS, J. C.; PEREIRA, A. R.; OSHIRO, L. M.; CUNHA, R. C.; FIGUEIREDO NETO, L. F. Association between seropositivity for Neospora caninum and reproductive performance of beef heifers in the Pantanal of Mato Grosso do Sul, Brazil. Revista Brasileira de Parasitologia Veterinária, São Carlos, v. 19, n. 2, p. 1-5, 2010.

ANUÁRIO DA PECUÁRIA BRASILEIRA ANUALPEC. São Paulo: Instituto FNP, 2008. 380 p.

BOI \& COMPANHIA. Informativo pecuário semanal. Bebedouro, São Paulo, n. 886, ano 17, 13 a 19 set. 2010. Disponível em: <http://xa.yimg.com/kq/ groups/13765267/2020835465/name/bc876_def.pdf>. Acesso em: 17 dez. 2010.

CADAVID GARCIA, E. A. Estimativa dos custos de produção da pecuária de corte do Pantanal Matogrossense. Corumbá: Embrapa-UEPAE de Corumbá, 1981. 75 p. (Circular técnica, n. 5).

Estudo técnico-econômico da pecuária bovina de corte do Pantanal Mato-grossense. Corumbá: Embrapa-CPAP, 1986, 150 p. (Documentos, n. 4).

CEZAR, I. M.; CORRÊA, E. S.; COSTA, F. P.; SOUZA, O. C.; AMARAL, T. B.; PORTO, J. C. A.; SILVA, M. P.; MAURO, R. A.; POTT, A.; MACEDO, M. C. A realidade bioeconômica do médio pecuarista: um estudo de caso em Mato Grosso do Sul. Campo Grande, MS: Embrapa Gado de Corte, 2005, 49 p. (Documentos, n. 154).

CORREAA, E. S.; COSTA, F. P.; MELO FILHO, G. A.; PEREIRA, M. A. Sistemas de produção melhorados para gado de corte em Mato Grosso do Sul. Campo Grande, MS: Embrapa Gado de Corte, 2006. (Comunicado técnico, n. 102).

COSTA, F. P.; CORRÊA, E. S.; FEIJÓ, G. L. D. Gerenpec: aplicativo para planejamento da fazenda de gado de corte. Campo Grande, MS: Embrapa Gado de Corte, 2004. 33 p. (Embrapa Gado de Corte. Documentos, n. 143).

COSTA, F. P.; CORRÊA, E. S.; MELO FILHO, G. A.; CEZAR, I. M.; PEREIRA, M. A. Sistemas e custos de produção de gado de corte em Mato Grosso do Sul Regiões de Campo Grande e Dourados. Campo Grande, MS: Embrapa Gado de Corte, 2005. (Comunicado técnico, n. 93).

COSTA, F. P.; CORRÊA, E. S.; MELO FILHO, G. A.; CARDOSO, E. E. Custos de produção de gado de corte em Mato Grosso do Sul - setembro de 2007. Campo Grande, MS: Embrapa Gado de Corte, 2008. (Comunicado técnico, n. 111).

DUBEY, J. P.; CARPENTER, J. L.; SPEER, C. A.; TOPPER, M. J.; UGGLA, A. Newly recognized fatal protozoan disease of dogs. Journal of the American Veterinary Medical Association, New York, v. 192, n. 9, p. 1269-1285, 1988.

DUBEY, J. P.; SCHARES, G. Diagnosis of bovine 
neosporosis. Veterinary Parasitology, Amsterdam, v. 140, n. 1/2, p. 1-34. 2006.

DUBEY, J. P.; SCHARES, G.; ORTEGA-MORA, L. M. Epidemiology e control of neosporosis and Neospora caninum. Clinical Microbiology Reviews, Washington, v. 20, n. 2, p. 323-367, 2007.

EMPRESA BRASILEIRA DE PESQUISA AGROPECUÁRIA - EMBRAPA GADO DE CORTE. Gerenpec. Disponível em: <http://www.cnpgc.embrapa. $\mathrm{br} /$ produtoseservicos/gerenpec/index.html $>$. Acesso em: 17 dez. 2010.

HOLANDA JÚNIOR, E. V.; MADALENA, F. E.; HOLANDA, E. D.; MIRANDA, W. M.; SOUZA, M. R. Impacto econômico da mastite em seis fazendas de Araxá - Minas Gerais, Brasil. Archivo Latinoamericanos de Produccion Animal, Maracaibo, v. 13, n. 2, p. 63-69, 2005.

JORGE JÚNIOR, J.; CARDOSO, V. L.; ALBUQUERQUE, L. G. Modelo bioeconômico para cálculo de custos e receitas em sistemas de produção de gado de corte visando à obtenção de valores econômicos de características produtivas e reprodutivas. Revista Brasileira de Zootecnia, Viçosa, v. 35, n. 5, p. $2187-$ 2196, 2006.

LEVINE, D. M.; BERENSON, M. L.; STEPHAN, D. Estatística: teoria e aplicações. Rio de Janeiro: LTC, 2000. $811 \mathrm{p}$.

LOPES, M. A.; CARVALHO, F. M. Custo de produção do gado de corte. Lavras: Editora UFLA, 2002. (Boletim técnico, n. 47). Disponível em: <http://www.editora.ufla. br/site/_adm/upload/boletim/bol_47.pdf>. Acesso em: 20 abr. 2009.

OLIVEIRA, J. M.; MATOS, M. F. C.; OSHIRO, L. M.; ANDREOTTI, R. Prevalence of anti-Neospora caninum antibodies in dogs in the urban area of Campo Grande, MS, Brazil. Revista Brasileira Parasitologia Veterinária, São Paulo, v. 13, n. 4, p. 155-158, 2004.

OSHIRO, L. M.; MATOS, M. F. C.; OLIVEIRA, J. M.; MONTEIRO, L. A. R. C.; ANDREOTTI, R. Prevalence of anti-Neospora caninum antibodies in cattle from the state of Mato Grosso do Sul, Brazil. Revista Brasileira de Parasitologia Veterinária, São Carlos, v. 16, n. 3, p. $133-138,2007$.

PARÉ, J.; THURMOND, M. C.; HIETALA, S. K. Congenital Neospora caninum infection in dairy cattle and associated calfhood mortality. Canadian Journal of Veterinary Research, Ottawa, v. 60, n. 2, p. 133-139, 1996.

PAZ, G. F.; LEITE, R. C.; ROCHA, M. A. Associação entre sorologia para Neospora caninum e taxa de prenhez em vacas receptoras de embriões. Arquivo Brasileiro de Medicina Veterinária e Zootecnia, Belo Horizonte, v. 59, n. 5, p. 1323-1325, 2007.

SCHWARTZ, P. A arte da visão de longo prazo: planejando o futuro em um mundo de incertezas. São Paulo: Best Seller, 2000. 216 p.

VALLE, E. R. (Ed.). Boas práticas agropecuárias bovinos de corte. 2. ed. Campo Grande, MS: Embrapa Gado de Corte, 2010. 67 p.

VIEIRA, A.; LOBATO, J. F. P.; CORRÊA, E. S.; TORRES JÚNIOR, R. A.; COSTA, F. P.; CEZAR, I.. M. Desempenho produtivo nas fases de cria e recria em um sistema de produção de gado de corte no Brasil Central. Campo Grande, MS: Embrapa Gado de Corte, 2005. (Boletim de Pesquisa e Desenvolvimento, 18).

VON BLUMRÖDER, D.; SCHARES, G.; NORTON, R.; WILLIAMS, D. J. L.; ESTEBAN-REDONDO, I.; WRIGHT, S.; BJO"RKMAN, C.; FROSSLING, J.; RISCO-CASTILLO, V.; FERNANDEZ-GARCIA, A.; ORTEGA-MORA, L. M.; SAGER, H.; HEMPHILL, A.; VAN MAANEN, C.; WOUDA, W.; CONRATHS, D. F. J. Comparison and standardization of serological methods for the diagnosis of Neospora caninum infection in bovines. Veterinary Parasitology, Amsterdam, v. 120, n. 1/2, p. 11-22, 2004.

ZIMMER, A. H.; EUCLIDES FILHO, K. As pastagens e a pecuária de corte brasileira. In: SIMPÓSIO INTERNACIONAL SOBRE PRODUÇÃO ANIMAL EM PASTEJO, 1., 1997, Viçosa. Anais... Viçosa, MG: UFV, 1997. p. 349-379. 